\title{
Ethnomathematics: Mathematical aspects of Panjalin traditional house and its relation to learning in schools
}

\author{
Herri Sulaiman ${ }^{1}$, Fuad Nasir ${ }^{1}$ \\ ${ }^{1}$ Universitas Swadaya Gunung Jati, Cirebon \\ $\triangle$ herrimsc@gmail.com
}

\author{
Article Information \\ Submitted Sept 01, 2020 \\ Revised Oct 10, 2020 \\ Accepted Oct 22, 2020
}

\section{Keywords}

Ethnomathematics;

Mathematics Learning;

Panjalin Traditional House.

\begin{abstract}
This study was aimed to improve the learning process at school through ethnomathematics culture-based learning, namely the Panjalin traditional house. The purpose of this study was to explore the culture of Panjalin society as a medium for learning mathematics. Through culture-based learning, students were expected to improve their mathematics learning outcomes. The results showed that there were mathematical concepts and activities in the Panjalin traditional house. Students should learn the theories about mathematical concepts and know their application. The result of the study was aimed to examine the aspects of mathematics in the Panjalin traditional house and its relationship with mathematics learning at schools.
\end{abstract}

\section{INTRODUCTION}

Ethnomathematics is a new and coherent study. As one of the new studies, ethnomathematics plays an important role in exploring the noble cultural values. According to D'Ambrosio (1985), ethnomathematics is mathematics practiced by cultural groups, such as indigenous peoples, labor groups, urban and rural communities, children of certain age groups, and others (D’Ámbrosio, 1985). Ethnomathematics is also aimed at studying how students understand, manage, and articulate so that they can use mathematical ideas, concepts, and practices that can solve mathematical problems at school and in the environment where they live (Sulaiman, 2019). In ethnomathematics, the habits cannot be separated from the application of mathematical concepts. This can be seen from the forms of cultural products, especially in Indonesia, such as art, the shapes of traditional houses, carvings, and jewelry. Ethnomathematics uses broad mathematical concepts related to various mathematical activities including grouping activities, counting, measuring, designing buildings or tools, playing, determining locations, and so on (Rachmawati, 2012). The concept is very important, but how the concept can be understood by students. The concept of understanding the learning process affects students' attitudes, decisions, and problem-solving methods (Raharjo et al. 2017). According to Pramuditya \& Sulaiman (2019). One of the innovations assisting the improvement of student understanding is the development of innovative and progressive learning to develop and explore knowledge concretely and independently.

The concept is dealing with students' understanding of an aspect of mathematics tailored to the cultural activities in their environment. Mathematics is very close to the habits of society, especially the people of West Java. Without realizing it, some Javanese or tribal people with 
certain cultures have used mathematical knowledge in their daily activities. Be it simple or complex, activities such as buying and selling fish caught at the coastal fishing complex or building traditional houses where every part of the ornament of the building is calculated in detail and systematically. Among the many fields of mathematics, geometry includes transformation geometry, field and space analytic geometry, and Euclid's geometry (Sundawan et al. 2019). Geometry is a branch of mathematics that deals with points, straight lines, plane numbers, space, spatial, and the relationship between them (Yunita et al. 2019). One of the roles of geometry in mathematics is to develop thought processes because geometry has quite complex elements. Geometry is an order that leads the designer to efficiently achieve what he desired to be 'beautiful'. The geometrical rules are binding and directing a design toward a specific goal. Without these rules, architects are merely masons who meaninglessly arrange stones (Firmasari \& Sulaiman, 2020). Geometry is used by everyone in everyday life and occupies a unique position in the mathematics curriculum due to the many concepts it contains (Maharani et al. 2019).

The ethnomathematical studies can be found in the Panjalin Kidul village called the traditional house of Panjalin. The Panjalin traditional house is one of the traditional houses that has various stories. The name "Panjalin" is taken from the word Penjalin which means the rattan forest. According to the caretaker of this house, the house is built using a giant tree trunk without cutting the tree. The roots of the tree were located under the Panjalin traditional house. The Panjalin traditional house was built by Raden Sanata. He was a descendant of Talaga who studied at the Pager Gunung boarding school. Raden Sanata married Seruni who was the daughter of a Penjalin village elder, namely Raja Syahrani. Raja Syahrani himself was a descendant of Cirebon who lived, died, and buried in Panjalin. His activity was spreading Islam. The following is an image of the Panjalin traditional house.

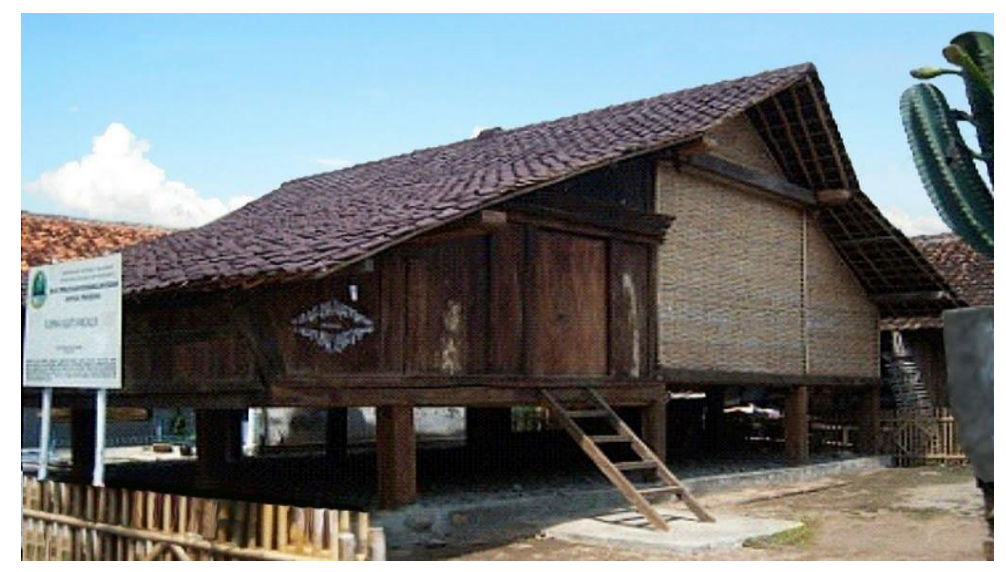

Figure 1. Panjalin Traditional House

Physically, the house stands on stilts with 16 supporting poles from wooden beams measuring $9 \times 9 \mathrm{~m}$. It occupies an area of $172 \mathrm{~m}^{2}$. This house is divided into two parts, namely the front space and the inner space. The front space is used to receive guests while the inner space functions as a space to rest. The two sections are bordered by a row of wooden planks and equipped with a door. The mathematical aspects of the Panjalin traditional house can be studied deeply. Furthermore, by using culture as a learning resource, it is hoped that students 
will be able to understand mathematical concepts by providing examples and cons and developing concepts that have been learned (Raharjo \& Sulaiman, 2017).

Relevant research was conducted by Utami (2018) with the title "Learning Resources Exploration of Lampung Traditional House Design (Lamban Dalom): an Ethnomathematics Perspective". Her research discovered that book is not the only learning resources because the environment and local culture can be more meaningful for students. Another research was conducted by Hariastuti (2018) with the title "Concepts of Banyuwangi Traditional Houses as a Basis for the Development of Ethnomathematics-Based Contextual Learning". She discovered that the construction of traditional houses involves geometric, congruence, geometric transformations, especially reflections, and fractal geometry concepts. Research by Rahmawati and Muchlian (2019) with the title "Ethnomathematics Exploration of Rumah Gadang Minangkabau West Sumatra" discovered that in constructing a Rumah Gadang, mathematical elements and concepts are implemented. Without studying the theory of these mathematical concepts, the Minangkabau people have applied mathematical concepts in their daily lives using ethnomathematics. Research by Herlina et al. (2018) with the title "Ethnomathematics in the Traditional Houses of Palembang. In this study, there are many mathematical concepts applied in Palembang traditional houses so that they can be an alternative source of learning mathematics. They can also increase students' insight on culturebased mathematics elements and can increase students' learning motivation in relating concepts that are studied in real-world situations.

The previously mentioned research and the research conducted by the researchers have a common concept, namely the exploration of ethnomathematics forms that can be found in the traditional houses. Both kinds of research explore the mathematical aspects of an object. The novelty of this research is that the object is the Panjalin traditional house in Panjalin Kidul village, Majalengka district, West Java province which has never been researched and studied, especially in the field of ethnomathematics studies. Also, the mathematical aspects found in the Panjalin traditional house consist of flat geometric elements, geometrical sequences, and rows. Then, what distinguishes this research from previous research and can be used as the latest findings are the way to describe mathematical patterns and theories through concepts and steps that the researchers have compiled and explained. The philosophical meaning contained in the Panjalin traditional house can be known and found along with the mathematical aspects so that the ethnomathematical exploration of the Panjalin traditional house can be deeper and detailed. Furthermore, the mathematical aspects found in Panjalin traditional house can be linked to the school learning and adjusted to the existing syllabus in the 2013 curriculum so that the teachers' needs in teaching ethnomathematics-based discovery learning can be identified.

\section{METHODS}

This research was qualitative. This study was aimed to uncover mathematical concepts in the Panjalin traditional house as a result of the mutual influence between mathematics and culture. The method used was a descriptive method with an ethnographic approach and case study. In determining the location and sample of research, the researchers used purposive sampling. The site of research was in Panjalin Kidul Village, Sumberjaya District, Majalengka Regency. The subjects of this research were the descendants of Raden Sanata named Iang Saeful Ikhsan. The object of this research was the Panjalin traditional house. 
Direct observation and interview techniques were used in this research with observation sheets and interview sheets as the research instruments. The data analysis had been carried out before, during, and after entering the field. The following is the chart of the research process:

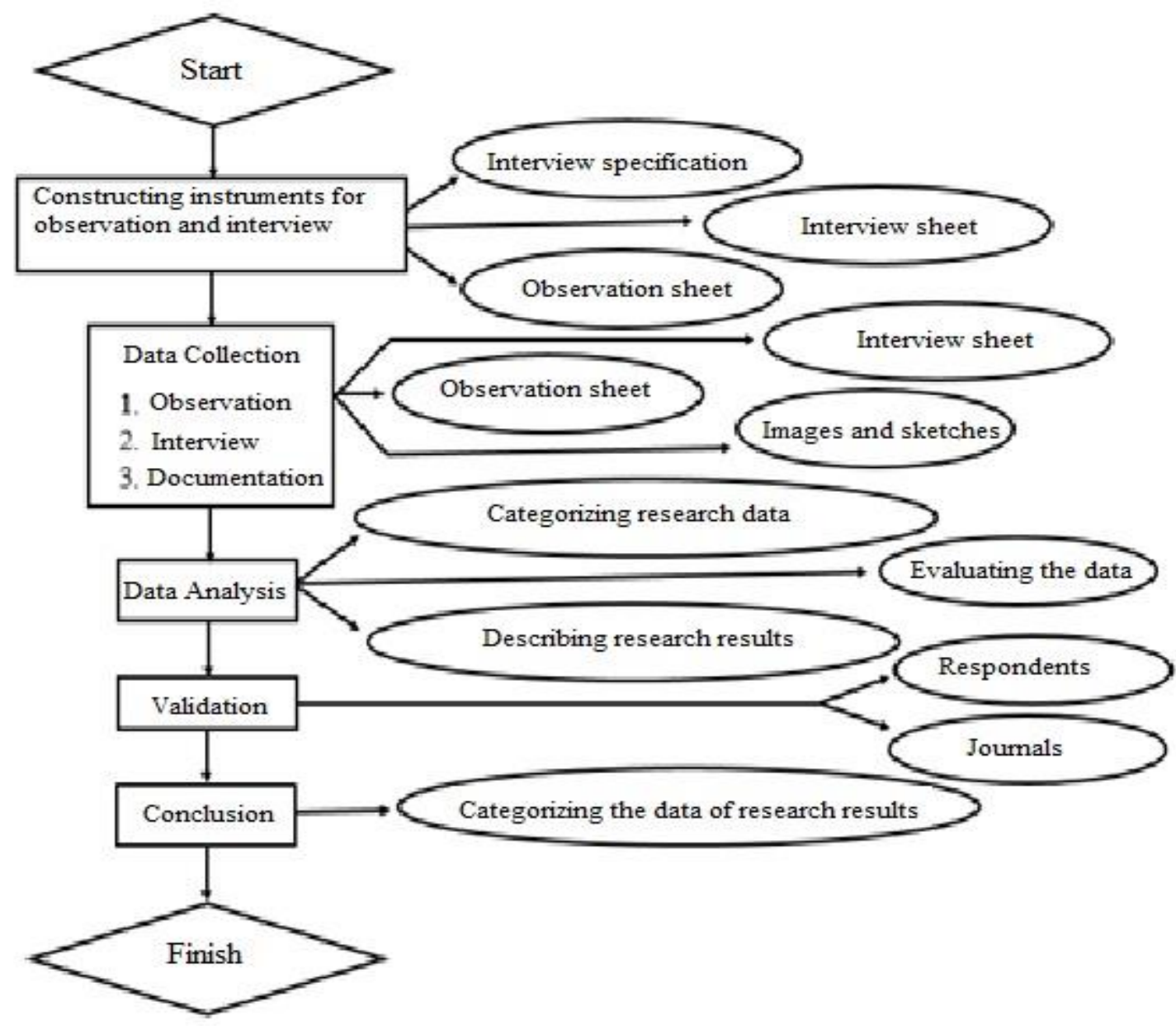

Figure 1. The Flowchart of the Research

\section{RESULTS AND DISCUSSION}

The Panjalin traditional house is a building believed to be a historical relic that still exists. It is located at Blok Rabu RT/RW 01/05, Panjalin Kidul Village, Sumberjaya District, Majalengka Regency, West Java. It is about $23 \mathrm{~km}$ from Majalengka. The distance between the main road and the traditional house is about $200 \mathrm{~m}$. Astronomically, this house is located at coordinates $6^{\circ} 41^{\prime} 51^{\prime \prime}$ South Latitude and $108^{\circ} 21^{\prime} 25^{\prime \prime}$ East Longitude. The following is an image of the Panjalin traditional house. 


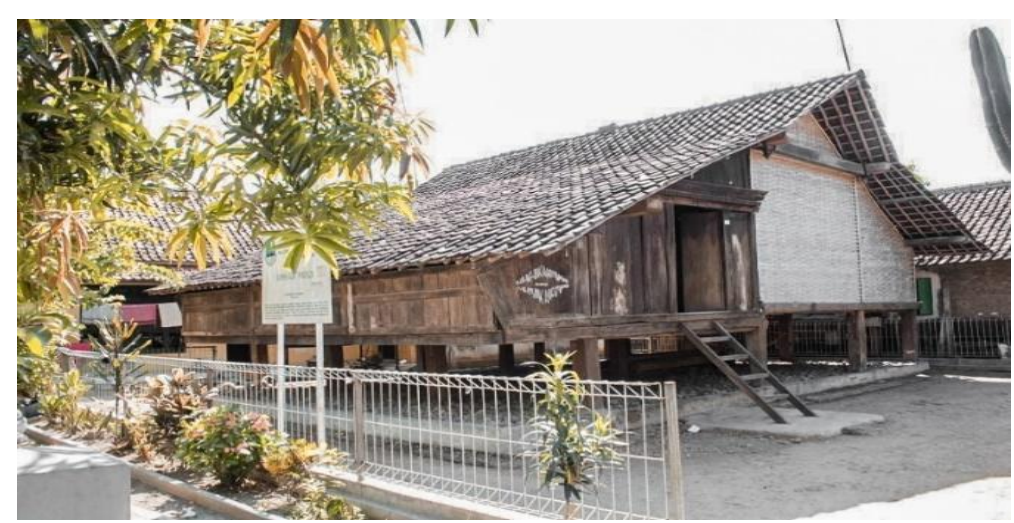

Figure 2. Panjalin Traditional House

Based on an interview with Mr. Iang Saeful Ikhsan as the descendant and manager (kuncen) of the traditional house, the history of the Panjalin traditional house had been obtained. He said that the Panjalin traditional house contains the philosophy of life in the establishment of the traditional house. This means that upon entering a household life, clothing, food, and shelter must be fulfilled. The traditional house is in the form of a stage. The stage itself represents that life needs improvement. The supporting poles use tree trunks without cutting the tree. It has a philosophy that friendship must be tightly established. The pillars of the Panjalin traditional house can be seen in Figure 3.

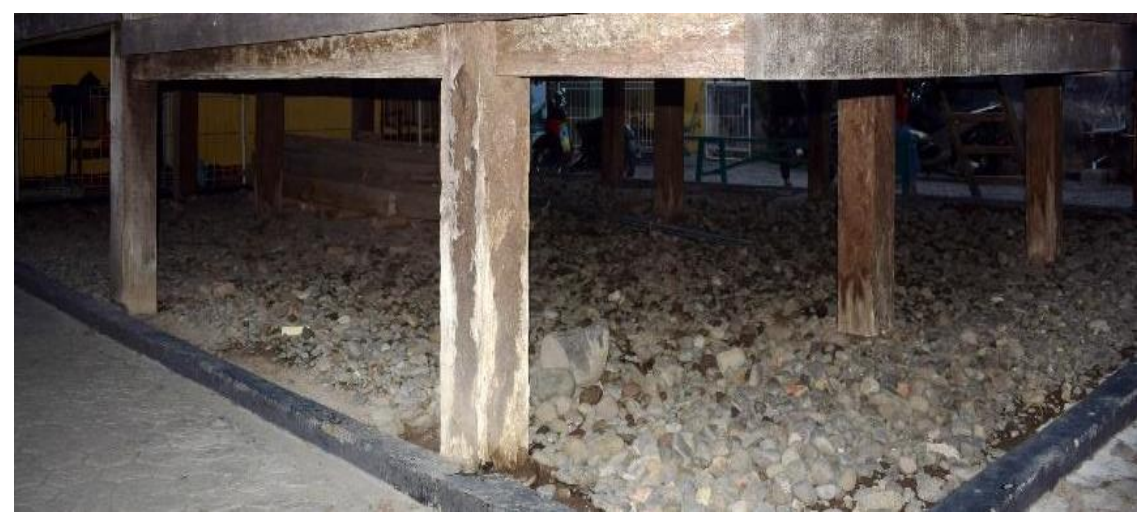

Figure 3. The Pillars of the Panjalin Traditional House

The traditional house has one building that represents Tawheed to Allah the almighty. Humans are created by Allah so that $\mathrm{He}$ is the only one worthy of worship. The traditional house has two doors, consisting of the main door and the second door. The doors represent parents whom children should not forget. The followings are the images of the main door and the second door of the Panjalin traditional house:

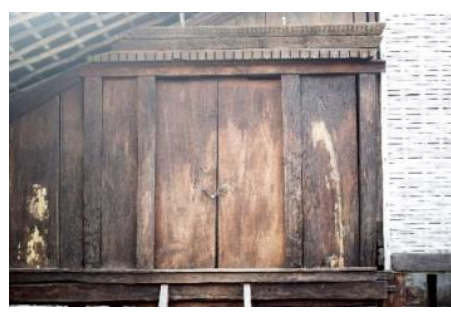

(a) Main Door
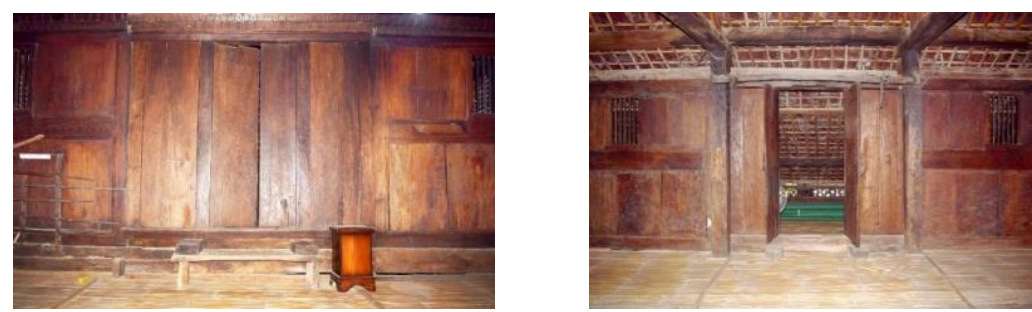

(b) Second Door

Figure 4. The Doors of the Panjalin Traditional House 
The Sundanese script located at the front-left side of the traditional house says "megat karuhun mupus katurunan". It means that removing inheritance is the same as breaking the family bond (Figure 5). At the entrance to the Panjalin traditional house, there is an ornament in the form of geometric carving which represents that life has social levels (Figure 6).

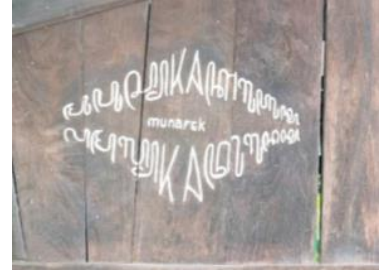

Figure 5. Sundanese Script

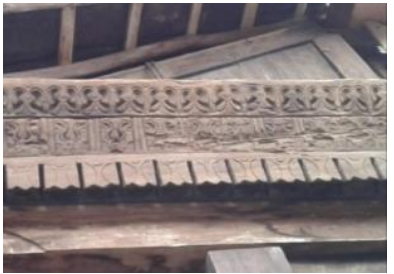

Figure 6. Carved Ornaments

The panjalin traditional house also has a unique air ventilation shape. The air ventilation has a bird motif and starling tracks. The bird motif in the Panjalin traditional house means that the house is occupied by Raden Sanata. Raden Sanata's nickname was prince over the wind. The nickname represents that Raden Sanata has higher knowledge. The starling tread motif contains an anti-magic philosophy. In the past, the surrounding community believed in magic. The followings are the images of the air ventilation of the Panjalin traditional house:

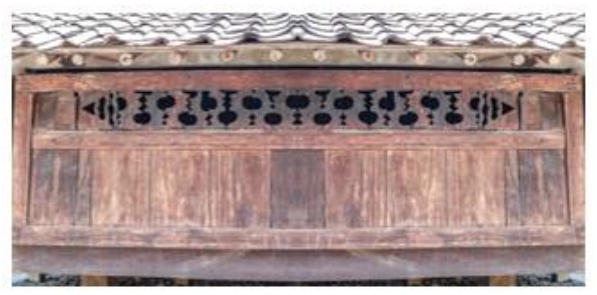

Figure 7. Air Ventilation

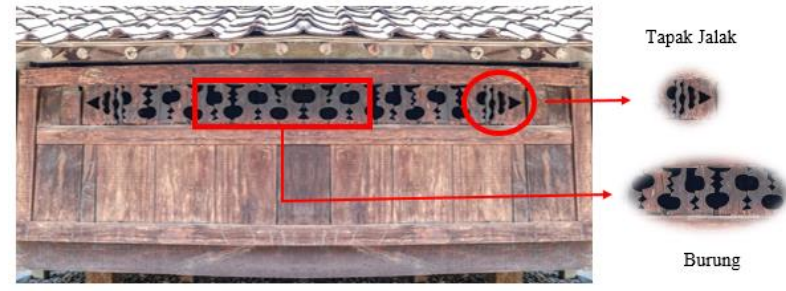

Figure 8. Description of Motive on Air Ventilation

The front wall of the house is made of rows of wooden planks with geometric decorations at the top of the door. The inside of the house consists of wooden walls and bamboo floors. Suhunan (roof) of the house is shaped slowly using clay tiles. The traditional house of Panjalin is in the form of a Julang Ngapak. The sketches of the Panjalin traditional house can be seen in the following figures.

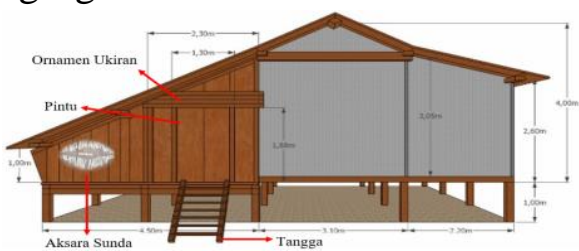

(a) Front View

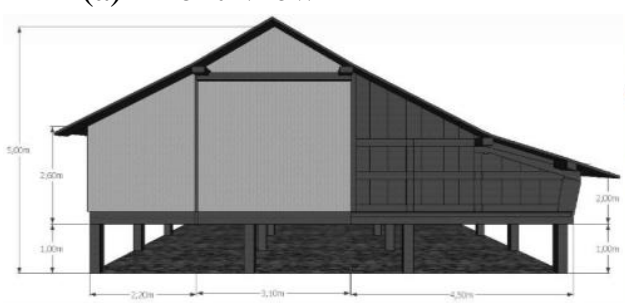

(b) Rear View

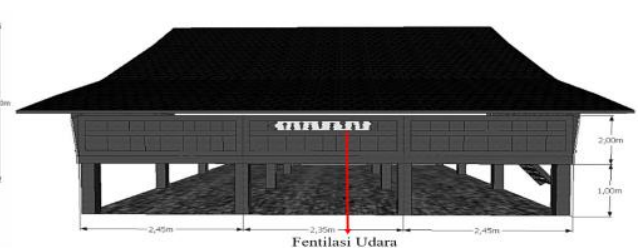

(c) Left Side View

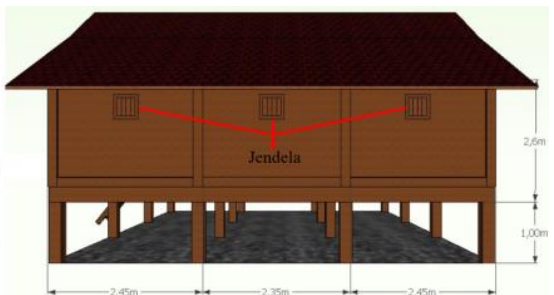

(d) Right Side View

Figure 9. The Sketches of Panjalin Traditional House 
Guests must first climb the ladder at the doorway to enter the house. Four steps must be climbed to get in. Once you enter the interior of the house, you will see two rooms that have the same area. The two rooms are called tepas (front room) and pangkeng (bedroom). The ceiling of the house is furnished with quite beautiful works of art, namely geometric artworks.

Table 1. The Functions of Panjalin Traditional House

\begin{tabular}{cll}
\hline No & Parts of Panjalin Traditional House & \multicolumn{1}{c}{ The function of Panjalin Traditional House } \\
\hline 1. & Front room (main) & The front room functions as a living room \\
2. & Inner room & The inner room functions as a family room \\
\hline
\end{tabular}

\section{Mathematical Aspects of the Panjalin Traditional House}

Even though the ancient community when building the Panjalin traditional house did not know mathematics and did not use a standard unit of measurement, it turns out that various parts of the traditional house indicated measuring and designing activities that produce various symmetrical motifs. Based on the results of research, several mathematical aspects are found in the Panjalin traditional house, one of which is plane geometry.
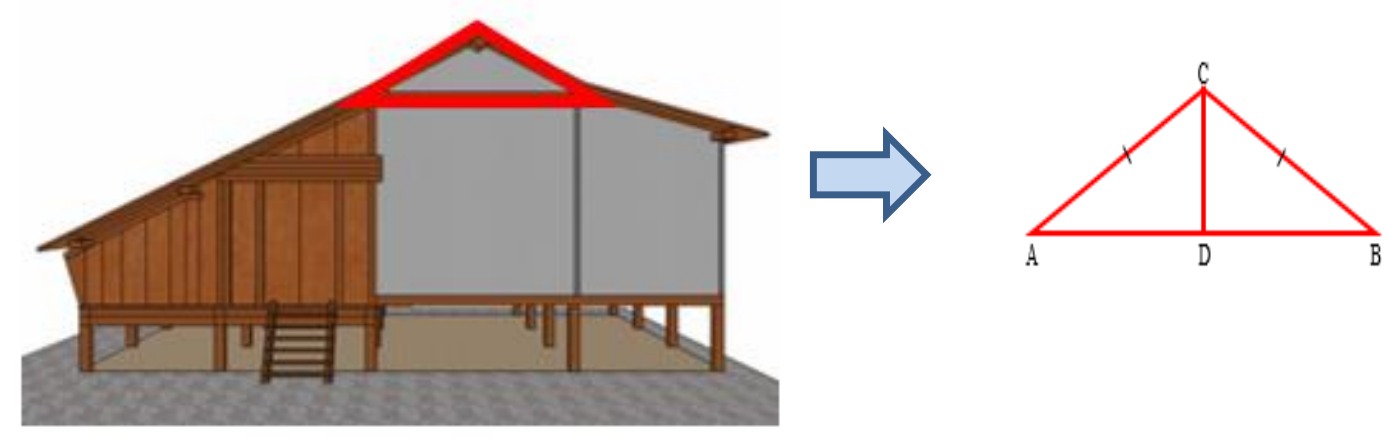

Figure 10. The Roof of the Panjalin Traditional House Is Triangular

Based on Figure 10, the roof of the Panjalin traditional house uses a mathematical concept in the form of an isosceles triangle. In general, the isosceles triangle consists of equal angles. When bisectors $\mathrm{B}<B$ are drawn, then $\triangle A B C$ and $\triangle C B D$ of the triangle can be represented by $\overline{A B} \cong \overline{C B}, m<A B D=m<C B D$, and $\overline{B D} \cong \overline{B D}$. Therefore, $\angle A B D \cong<C B D$ is $m<$ $A B D=m<C B D=90^{\circ}, \overline{A D} \cong \overline{D C}$. Thus, $D$ is the midpoint of $\overline{A C}$. The followings are the illustration of an isosceles triangle adapted to the shape of the roof of the Panjalin traditional house.

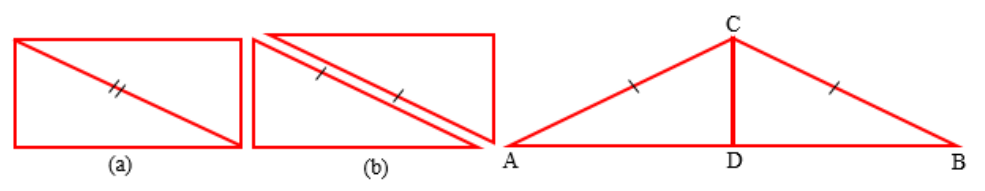

Figure 11. The Illustration of the Roof Shape of Panjalin Traditional House

If the isosceles triangle in Figure 11 (a) is cut according to one of its diagonals, two congruent right triangles are obtained as shown in figure 11 (b) and if the two right triangles are combined, a triangle shape is formed as shown in Figure 11. (c). It appears that the triangle has two sides which are marked the same. Such a triangle is called an isosceles triangle. Since the isosceles triangle, $A B C$ is made up of two congruent right triangles, the sides and angles are the same. So it can be said that the lines $\overline{A C}$ and $\overline{B C}$ are called feet, $\overline{A B}$ is called the base. Where $\angle C D A=\angle C B D(\angle A=\angle B)$ is called the base angle, $\angle A C B$ is called the vertex angle. 
Furthermore, $\angle A$ in front of lines $\overline{B C}$ and $\angle B$ is in front of line $\overline{A C}, \overline{A C=\overline{B C}}$, and $\angle A=\angle B$. In other words, it can be concluded that the angles facing the legs of the same length are the same, and vice versa. If the isosceles triangle $A B C$ in the image above is reversed along the $\overline{C D}$ axis, the isosceles triangle $A B C$ can occupy the frame correctly. Since $\overline{C D}$ is the axis of symmetry $\overline{A D}=\overline{B D}$ and $\angle A C D=\angle B C D$.

The roof of the house is in the shape of an isosceles triangle which is similar when with the shape of modern houses today. However, the roof of the Panjalin traditional house with today's modern house is certainly different because the Panjalin traditional house has a philosophical meaning and has the meaning of life in every part of its building. The triangleshaped roof of the Panjalin traditional house has a philosophical meaning, namely the hope of the descendants of Raden Sanata who had a high social rank but still submissive and obedient to Allah almighty. The point of the triangular shaped-roof of the Panjalin traditional house means that Allah is the highest position and humans, even though they have the highest social rank, are still subject to and obey His commands and prohibitions.

Besides, another plane shape is found, namely the square. This concept is found on the inside of the Panjalin traditional house. The images of the shape can be seen in Figure 12.
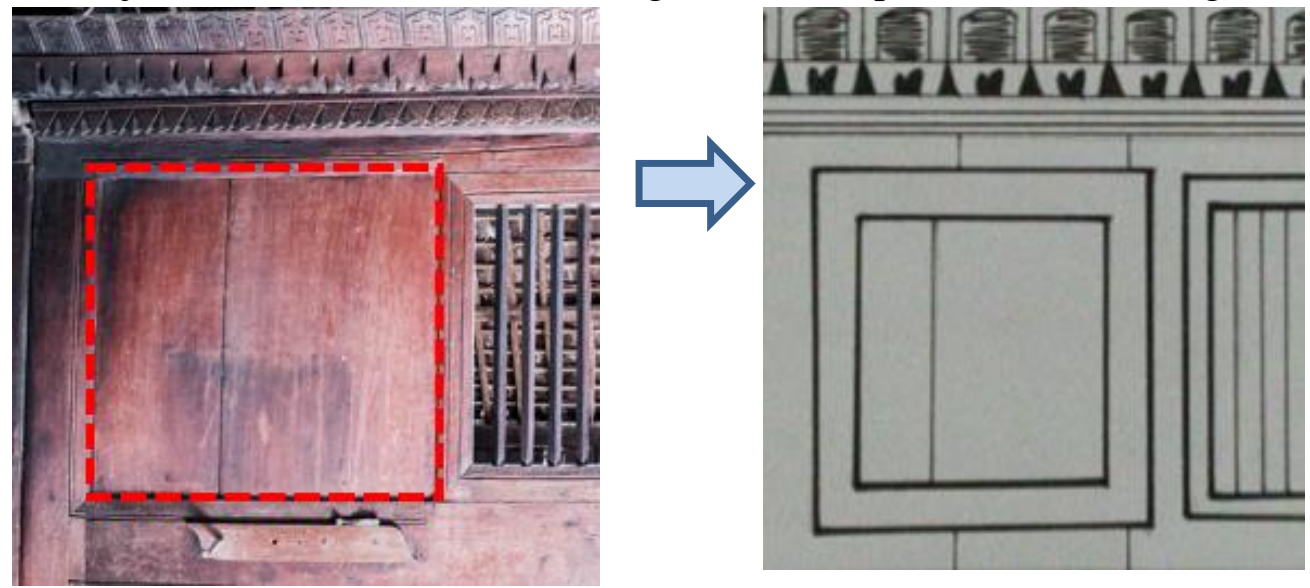

Figure 12. Square-Shaped Inner Walls of Panjalin Traditional House

It can be seen that the inner wall of the Panjalin traditional house applies the square mathematical concept. It is a quadrilateral which is a polygon that has four sides. When the figures above are observed, the properties of the square can be determined by reversing and turning the image. The following is the illustration.

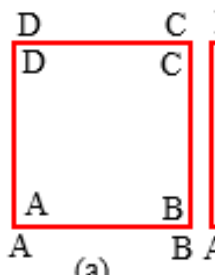

(a)

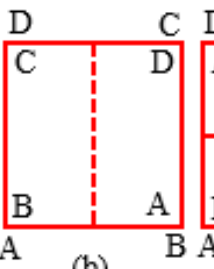

(b)

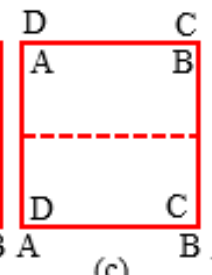

(c)

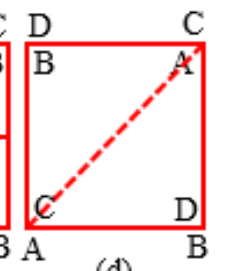

(d)

Figure 13. The Illustration of the Reversing and Turning Process of the Square

Figure 13 (a) shows the starting position where Figure 13 (b) shows the reversed position along the vertical axis of symmetry (vertical dotted line). Figure 13 (c) shows the reversed position along the horizontal axis of symmetry (horizontal dotted line) and Figure 13 (d) shows the $180^{\circ}$ turned position. From this figure, it can be seen that the locations of $a, b, c$, and $d$ are similar to the layout of the rectangle so that the properties of the rectangle are also applied. A 
square shape is a special rectangular shape because all of the properties contained in the rectangle are met by the properties of the square. If Figures 13 (a) and 13 (b) are observed, it will appear as follows:

(a) $A \rightarrow A, B \rightarrow D, \overline{A B} \rightarrow \overline{A D}$, thus $A B=A D$

$C \rightarrow C, B \rightarrow D, \overline{C B} \rightarrow \overline{C D}$, thus $C B=C D$

(b) $A \rightarrow C, B \rightarrow B, \overline{A B} \rightarrow \overline{C B}$, thus $A B=A B$

$A \rightarrow C, D \rightarrow D, \overline{A D} \rightarrow \overline{C D}$, thus $A D=C D$

Based on the description, $A B=C B=A D=C D$ so that the sides of a square are in the same length. A quadrilateral is a polygon that has four sides. $\overline{A B}, \overline{B C}$, and $\overline{A D}, \overline{C D}$ is called adjacent sides while $\overline{B C}, \overline{A D}$, and $\overline{A B}, \overline{C D}$ are called opposite sides. $\overline{A C}$ and $\overline{B D}$ are called diagonals. The pairs of angles $<A,<C$, and $<B,<D$ are called facing angles.

The philosophical meaning behind the square-shaped inner wall of the Panjalin traditional house is that humans have the same nature and degree as others. The square-shaped inner wall of the Panjalin traditional house consists of two parts, namely the left and right sides where the middle is a window that directly connects to the air outside the house. It represents that justice must be upheld by humans so that in the end they will find a way of peace. The meaning of the window in the middle of the square-shape wall is that when humans act fairly among each other, a way of peace will be seen which is wise and full of inner and outer peace.

Furthermore, the next mathematical concept found in the Panjalin traditional house is a geometric sequence. This concept is found on the outer wall of the Panjalin traditional house. The followings are the figures of the outer wall of the house.
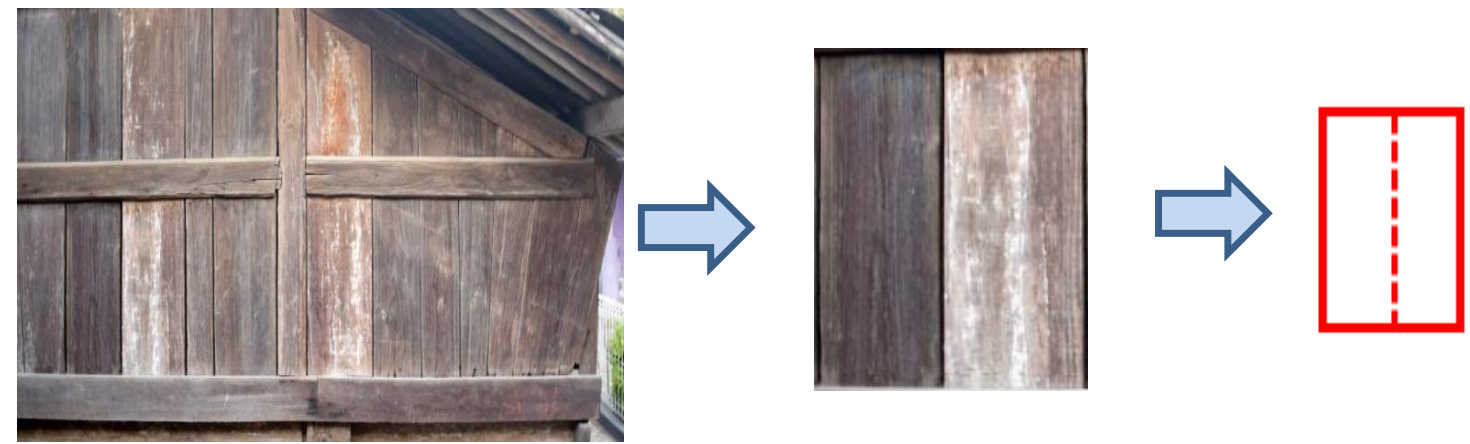

Figure 14. Outer wall Section of the Panjalin Traditional House

If Figure 14 is observed, it can be seen that the outer wall of the Panjalin traditional house uses mathematical concepts in the form of lines and rows. More complete illustration sketches can be seen in the following figure.

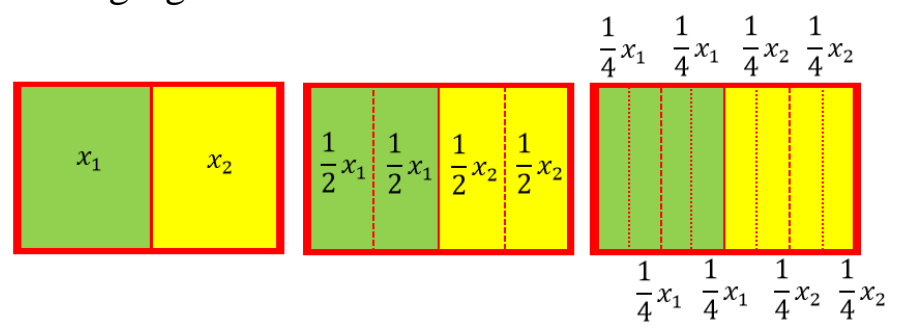

Figure 15. The Outer Wall Sketch of Panjalin Traditional House 
From Figure 15, it is clear that the outer wall of the Panjalin traditional house uses a mathematical concept, namely the concept of the geometric sequence as described below.

$$
2,4,8, \ldots
$$

Furthermore, when converted into geometric sequences, then:

$$
\frac{4}{2}=\frac{8}{4}=\frac{2.8}{2}=\frac{2.8 .2}{2.8}=\frac{U_{n+1}}{U_{n}}=2=r
$$

These results are in line with the definition of a geometrical sequence stated by Adinawann et.al (2010) that a geometric sequence is a sequence of $U_{1}, U_{2}, U_{3}, \ldots, U_{n}, U_{n+1}$. If every $n$ is a real number $\frac{U_{n+1}}{U_{n}}=\frac{U_{n}}{U_{n-1}}=\frac{U_{n-1}}{U_{n-2}}=\cdots=\frac{U_{2}}{U_{1}}=r$, so $2,4,8, \ldots$ are geometric sequences with the formula $U_{n}=2^{n}$, where $n=1,2,3, \ldots$

If it is further developed, a geometric series will be obtained. According to Purcell \& Valberg (1987), a series is defined as follows:

$$
\sum_{k=1}^{\infty} a r^{k-1}=a+a r+a r^{2}+a r^{3}
$$

$a \neq 0$ is called the geometric series of $S_{n}=\frac{a-a r^{n}}{1-r}=\frac{a}{1-r} \cdot \frac{a}{1-r} r^{n}$ where $r \neq 1$. However, if $|r|<1$, then $S_{n}=\frac{a}{1-r}$. If the existing sequences are formed in a series, it will be as follows:

$$
\frac{1}{2}+\frac{1}{4}+\frac{1}{8}+\frac{1}{16}+\cdots=\cdots
$$

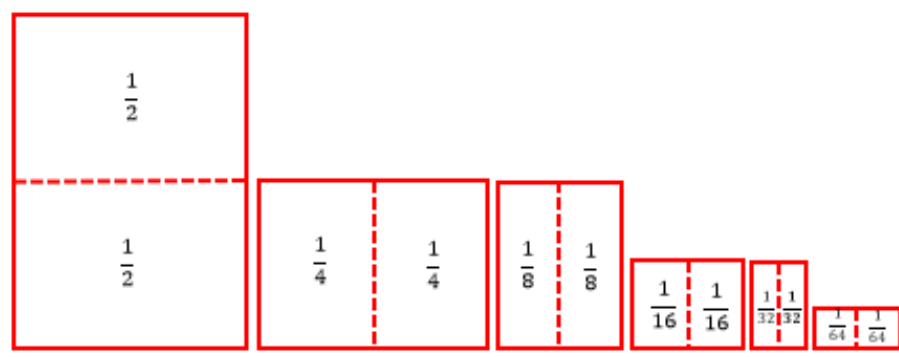

Figure 16. Illustration of the Geometric Sequence

Figure 16 is illustrated as a paper that cuts each wood on a dotted line or takes half of it, then the wood can be arranged as follows:
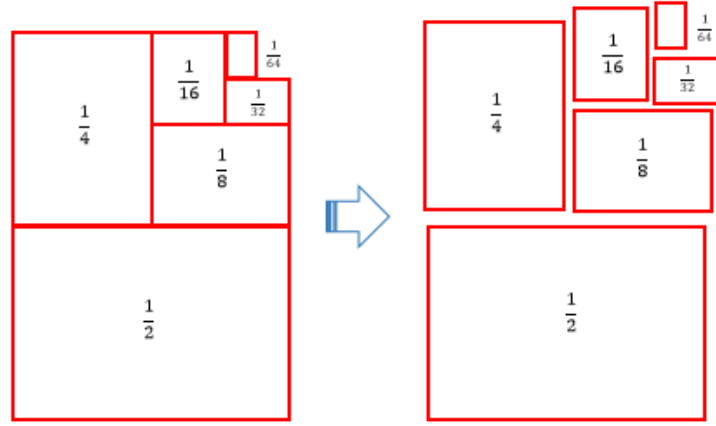

Figure 17. The Illustration of Geometric Series 
When the paper in Figure 17 is added to $\frac{1}{128}, \frac{1}{256}, \frac{1}{512}, \ldots$ it can be assumed that the separate arrangement of images will return to a full wooden form so that the number of the row is one. If it is examined with the existing theorem, then:

$$
S_{n}=\frac{a}{1-r}, S_{n}=\frac{\frac{1}{2}}{1-\frac{1}{2}}=\frac{\frac{1}{2}}{\frac{1}{2}}=1
$$

The results of the previously described illustration and theorem show the similarity of the results regarding the infinite geometric series. This shows that the illustration is in line with the calculations.

\section{The Relationship between the Mathematical Aspects of the Panjalin Traditional House and Mathematics Learning at School}

An approach in mathematics learning that can connect mathematics with culture is needed. Based on the research, there is a relationship between the mathematical concepts and the Panjalin traditional house. The concept of plane geometry contained in the Panjalin traditional house can be used as a learning resource to be adapted to the 2013 curriculum syllabus for junior high school level. The following table is the mapping of learning resources adjusted to the explanation of the mathematical aspects in the Panjalin traditional house.

Table 2. Mathematics Learning Resources Syllabus of Curriculum 2013 for Junior High School

\begin{tabular}{|c|c|c|c|}
\hline No. & Learning Material & Learning Implementation & Syllabus \\
\hline 1. & Isosceles Triangle & $\begin{array}{l}\text { Identifying and explaining objects with } \\
\text { triangular-shaped surfaces and solve real } \\
\text { problems related to the application of the } \\
\text { properties and concept of triangles. }\end{array}$ & $\begin{array}{c}\text { Mathematics syllabus of } \\
\text { curriculum } 2013 \text { for the } \\
\text { second semester of grade } \\
\text { VII }\end{array}$ \\
\hline 2. & Square & $\begin{array}{l}\text { Identifying and explaining objects with } \\
\text { square surfaces and solve real problems } \\
\text { related to the application of square } \\
\text { properties and concepts. }\end{array}$ & $\begin{array}{c}\text { Mathematics syllabus of } \\
\text { curriculum } 2013 \text { for the } \\
\text { second semester of grade } \\
\text { VII }\end{array}$ \\
\hline 3. & $\begin{array}{c}\text { Geometric Sequences } \\
\text { and Series }\end{array}$ & $\begin{array}{l}\text { Observing everyday problems related to } \\
\text { geometric sequences and series. }\end{array}$ & $\begin{array}{l}\text { Mathematics syllabus of } \\
\text { curriculum } 2013 \text { for the } \\
\text { second semester of grade IX }\end{array}$ \\
\hline
\end{tabular}

Based on the results of the analysis, the ethnomathematical forms of the Panjalin traditional house consist of mathematical concepts in the form of architecture and materials. The mathematical aspects of the Panjalin traditional house are the mathematical concepts of plane shapes and sequences and series. The following figures show a flowchart of the mathematical concepts contained in the Panjalin traditional house and a fishbone diagram that is often used to analyze the causes of a problem. 


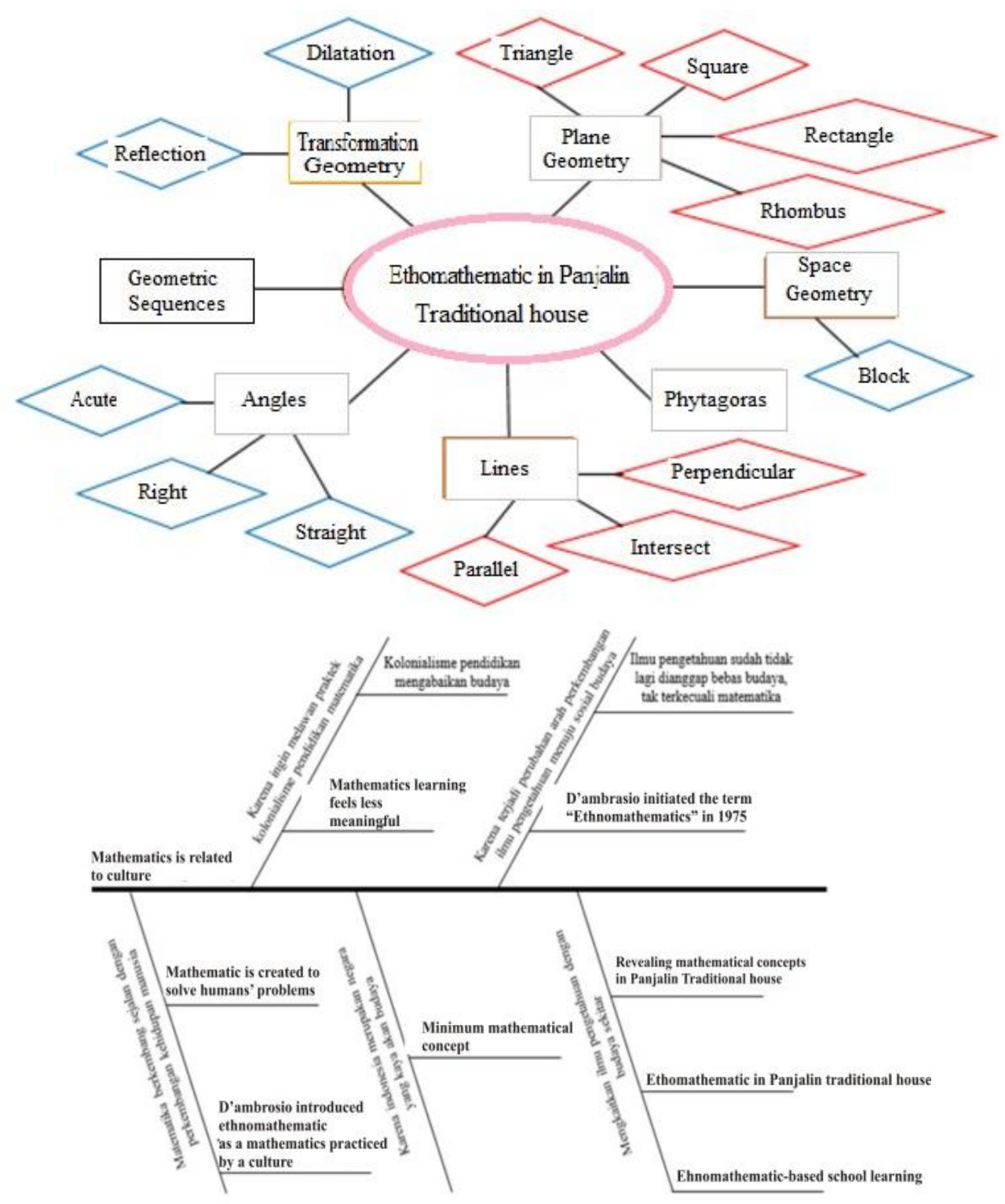

Figure 18. Mathematical Concepts Flowchart and a Fishbone Diagram

\section{CONCLUSIONS}

Based on the discussion presented in the previous chapter, it can be concluded that there are mathematical aspects contained in the Panjalin traditional house of Panjalin village, Majalengka district. for the learning benefits, students can learn mathematical concepts regarding planes and geometric lines and series directly at the location through guided discovery learning model so that the learning objectives can be achieved, namely, students can understand the concept more deeply because they are directly involved in researching and examining the mathematical aspects that exist in the Panjalin traditional house through teachers' guidances.

Besides learning mathematics, students also get the philosophical meaning of the Panjalin traditional house and know the history of the traditional house so that character education can be instilled optimally. Also, the discovery of the mathematical aspects of the Panjalin traditional house can be used as a learning resource for students in the form of an ethnomathematics-based 
learning module. This module can be used as an additional learning supplement for students to better understand and understand the basic concepts of mathematics.

Thus, the mathematical aspects of the Panjalin traditional house consist of geometric concepts for plane shapes and geometric lines and series. These mathematical aspects can be found in the corners of the room, the inside walls, the outside wall, and the roof of the Panjalin traditional house. Besides, the philosophical meaning contained in the Panjalin traditional house can also be traced. Every form of architecture of a traditional house contains meaning for selfevaluation so that students can reflect good behavior towards parents, others, and Allah the almighty. Thus, the character education expected by the government through the curriculum 2013 can be carried out optimally.

\section{AUTHOR CONTRIBUTIONS STATEMENT}

This article was conceptualized and original written by HS. FN participated in the methodology, validation and data curation. For review and editing carried out by all authors.

\section{REFERENCES}

D'Ambrosio, U. (1985). Ethnomathematics and its place in the history and pedagogy of mathematics. For the Learning of Mathematics, 5(1), 44-48.

Firmasari, S., \& Sulaiman, H. 2020. Analisis geometri fraktal pada bentuk bangunan di komplek keraton kanoman Cirebon. Euclid, 7(1), 51-60.

Hariastuti, R. M. (2018). Kajian konsep-konsep geometris dalam rumah adat using banyuwangi sebagai dasar pengembangan pembelajaran kontekstual berbasis etnomatematika. Aksioma, 7(1), 13-21.

Herlina, R., Somakim, S., \& Yusuf, H. (2018). Uletnomatematika dalam budaya rumah adat Palembang. Prosiding Seminar Nasional Pendidikan Matematika Etnomatematika.

Maharani, A., Sulaiman, H., Aminah, N., dkk. 2019. Analyzing the student's cognitive abilities through the thinking levels of geometry van hiele reviewed from gender perspective. Journal of Physics: Conference Series. Volume 1188 No.1 Halaman 012066 penerbit IOP Publishing.

Pramuditya, S. A., \& Sulaiman, H. (2019). Analisis kebutuhan game edukasi mahasiswa dalam menyelesaikan materi prasyarat persamaan diferensial. Euclid, 6(1), 74-83.

Rachmawati, I. (2012). Eksplorasi etnomatematika masyarakat Sidoarjo. Ejournal Unnes, 1(1), $1-8$.

Raharjo, J. F., Sulaiman, H., \& Wahyuni, I. 2017. The study of mathematical modeling development based on realistic approach as prototype learning to improve students mathematical problem-solving ability in differential equation subject. Repository FKIP Unswagati.

Raharjo, J. F., \& Sulaiman, H. (2017). Mengembangkan kemampuan pemahaman konsep matematika diskrit dan pembentukan karakter konstruktivis mahasiswa melalui pengembangan bahan ajar berbantuan aplikasi education edmodo bermodelkan progresif pace (project, activity, cooperative and exercise). Teorema: Teori dan Riset Matematika, 2(1), 47-62. 
Rahmawati, Y., \& Muchlian, M. (2019). Eksplorasi etnomatematika rumah gadang minangkabau Sumatera Barat. Jurnal Analisa, 5(2), 123-136.

Sulaiman, H. (2019). Aktivitas matematika berbasis budaya pada masyarakat pesisir di pasar ikan gebang kabupaten Cirebon. Mapan: Jurnal Matematika dan Pembelajaran, 7(1), 6173.

Sundawan, M. D., Irmawan, W., \& Sulaiman, H. 2019. Kemampuan Berpikir Relasional Abstrak Calon Guru Matematika dalam Menyelesaikan Soal-Soal Non-Rutin pada Topik Geometri Non-Euclid. Mosharafa: Jurnal Pendidikan Matematika. Volume 8 No.2 Halaman 319-330.

Utami, A. (2018) Eksplorasi sumber belajar pada rancang bangun rumah adat lampung (Lamban Dalom) dengan perspektif etnomatematika. Undergraduate Thesis, UIN Raden Intan Lampung.

Yunita, D. R., Maharani, A., \& Sulaiman, H. (2019, April). Identifying of rigorous mathematical thinking on olympic students in solving non-routine problems on geometry topics. In 3rd Asian Education Symposium (AES 2018) (pp. 495-499). Atlantis Press. 